\title{
SEISMIC CAPACITY ASSESSMENT OF UNREINFORCED BRICK MASONRY BUILDING PERFORMED ACCORDING TO EUROCODE
}

\author{
Raul Gautam* and Kshitiz Paudel \\ MSc in Earthquake Engineering, Department of Civil Engineering \\ Thapathali Campus, Institute of Engineering, Tribhuban University, Nepal \\ EE-mail: raulmesh22@gmail.com
}

\begin{abstract}
Brick Masonry Building with cement sand mortar is a common type of building typology in Nepal. Regardless of being one of the eldest construction technology, the behavior of masonry building is still a matter of study. The uncertainty in the behavior of masonry structures is due to material heterogeneity, complex behavior under different loading conditions and may be due to less research in this arena. Different modeling strategies are used and proposed worldwide to design and to identify the seismic performance of Masonry Building. The analysis strategy ranges from the simple linear method, equivalent frame method, static nonlinear method to dynamic nonlinear, which may be chosen according to engineering design aims and research purpose. In this attempt, authors choose two degrees of freedom 3D model of Unreinforced Brick Masonry Structures which catches both overturning and hysteresis mechanisms due to the shear response implemented by the TREMURI program with static nonlinear procedures. This verified method of modeling and analysis is applied to assess the performance of three different Unreinforced Brick Masonry buildings of the same plans with different numbers of storey.
\end{abstract}

\section{Keywords}

Macro modelling, Masonry Building, Pushover Analysis, Tremuri

\section{Introduction}

Masonry construction is one of the prevailing as well as eldest building techniques in Nepal as well as the globe. Masonry is defined as a structural assemblage of masonry units, such as stones, bricks, and blocks, with a binding material known as mortar. A built-up construction or combination of building units or materials of clay, shale, concrete, glass, gypsum, stone, or other approved units bonded together with or without mortar or grout or other accepted Methods of joining (International Code Council \& All, 2009). Normally these are designed for vertical loads and since masonry has adequate compressive strength, the structure behaves well as long as the loads are vertical. When these structures are subjected to lateral inertial loads during an earthquake, the wall develops shear and flexure stresses. The strength of masonry under these conditions often depends on the bond between units and mortar, which is quite poor. Shear failure in 
Nepal Engineers' Association, Gandaki the form of a diagonal crack is observed due to this (Adanur, 2010). Masonry buildings are being constructed in Nepal from early ages and are still in use in rural and semi-urban areas (Central Bureau of Statistics,2012). Most of the masonry building buildings are non-engineered and are vulnerable to earthquakes. Past earthquakes, as well as the Gorkha Earthquake followed by a series of aftershocks, demonstrate that the masonry buildings are vulnerable to earthquake, major loses of life was due to the collapse of masonry buildings. Damage in masonry buildings is mainly in load-bearing walls, gable walls, near-wall openings, and wall corners. Tilting, collapse of walls at roof level, out- of -plane wall failure, in-plane diagonal cracking, diagonal cracking around door or window opening, delamination of the wall and corner separation are the common failure pattern in these buildings. These are caused by poor material properties, poor construction detailing, improper geometrical configuration, unconfined gable walls, large openings, and lack of proper maintenance (Gautam et al,2016). These various deficiencies found in masonry buildings make them vulnerable to even a minor earthquake. So, it is necessary to study the behavior of masonry buildings. Accordingly, in this attempt authors perform static nonlinear analysis of various buildings of the same plans with different numbers of storey to assess the performance of three different Unreinforced Brick Masonry buildings.

\section{Structural Modeling and Seismic Analysis}

For this study, seismic responses of unreinforced brick masonry buildings having the same plan and different story are obtained numerically using a finite element-based software 3Muri.
The major inputs are the geometry of the building, storey height, total mass on the floor, and modulus of elasticity and earthquake data. For this analysis, vertical loads are taken according to Eurocode 6. Dead load applied at every floor is $1.5 \mathrm{kN} / \mathrm{m}^{2}$, Variable load at every floor (except the roof) is $2.5 \mathrm{kN} / \mathrm{m}^{2}$. Brick in cement sand mortar is considered as the load-bearing wall. The thickness of the wall is $350 \mathrm{~mm}$ and reinforce concrete slab is of thickness $125 \mathrm{~mm}$ is considered. The storey height is $3 \mathrm{~m}$ All the room size is $3.5 \mathrm{~m} \times 3.5 \mathrm{~m}$ and rigid floor diaphragm is considered. The size of the window is $900 \mathrm{~mm}^{*} 1000 \mathrm{~mm}$ and $1000 \mathrm{~mm} * 1200 \mathrm{~mm}$ respectively.

The structural description of the analyzed building and material property is shown in Table 1 and Table 2 respectively.

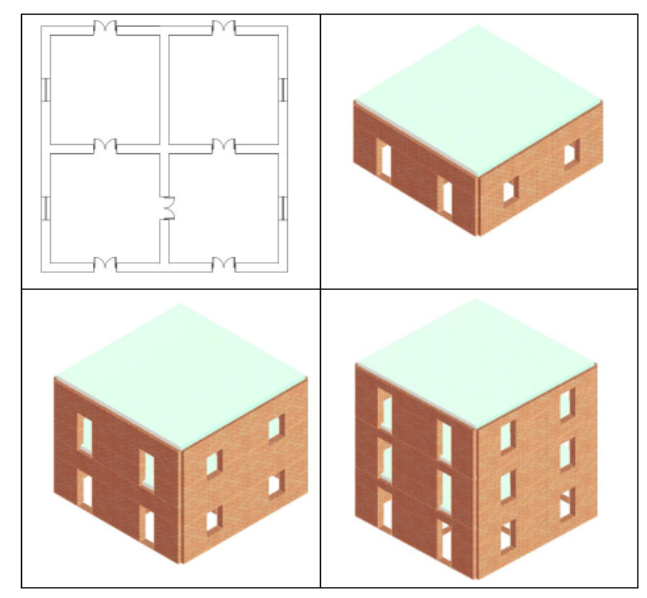

Figure 1: Plan and 3D building model with macro-elements setup through the TREMURI software.

Table 1: Structural Description of Analyzed Building

\begin{tabular}{|l|l|}
\hline Thickness of Wall: $350 \mathrm{~mm}$ & Storey Height: $3 \mathrm{~m}$ \\
\hline Slab Thickness: $125 \mathrm{~mm}$ & Room Size: $3.5 \mathrm{~m} * 3.5 \mathrm{~m}$ \\
\hline Size of Window: & Size of Door \\
$900 \mathrm{~mm} * 1000 \mathrm{~mm}$ & $: 1000 \mathrm{~mm} * 1200 \mathrm{~mm}$ \\
\hline
\end{tabular}


Table 2: Material Properties of Brick Cement Masonry (Kaushik et al. ,2007)

\begin{tabular}{|l|l|}
\hline Modulus of Elasticity & $2237 \mathrm{MPa}$ \\
\hline Shear Modulus & $932 \mathrm{MPa}$ \\
\hline Specific weight of masonry & $19 \mathrm{KN} / \mathrm{m} 3$ \\
\hline Poisson's Ratio & 0.2 \\
\hline Compressive Strength & $4 \mathrm{MPa}$ \\
\hline
\end{tabular}

Seismic input for analysis is taken from Eurocode 8 type 2 spectrum for soil type C and $\mathrm{a}_{\mathrm{gR}}=\mathrm{a}_{\mathrm{g}}=0.10 \mathrm{~g}$ (Building Importance Class II) represented the seismic input, in both principle directions $\mathrm{a}_{\mathrm{g}}=0.10 \mathrm{~g}$ was used for the verification of the ultimate limit state (ULS).

The equivalent frame approach along with their inelastic behavior was used implemented by the TREMURI program with pushover analysis procedures. All floor slabs are assumed to be rigid in their plane. The reduced stiffness of cracked sections was taken into account, assumed to be equal to one-half of the stiffness of corresponding homogenous sections.

According to provisions of Eurocode 8, Part 3; the capacity of individual elements in terms of drift limits was taken. In the case of the ULS, which is corresponding to the limit state of significant damage (SD) defined in the Part 3 of Eurocode 8, the drift limits taken into account amounted to $0.80 \%$ for flexure and $0.40 \%$ shear. Accidental torsional effects obtained through the application of eccentricity equal to \pm 0.05 times the building dimension are considered for both principal directions. Pushover analysis was performed by assuming the inversed triangular pattern of lateral force distribution.

The nonlinear macro-element approach, representative of a whole masonry panel, proposed by Gambarotta and Lagomarsino uses conventional macro-element used for pushover analysis is schematized with the kinematic model described as Figure 2. The 3D model of the examined masonry building, where it is apparent that masonry walls are modeled through a mesh of masonry spandrels and piers.
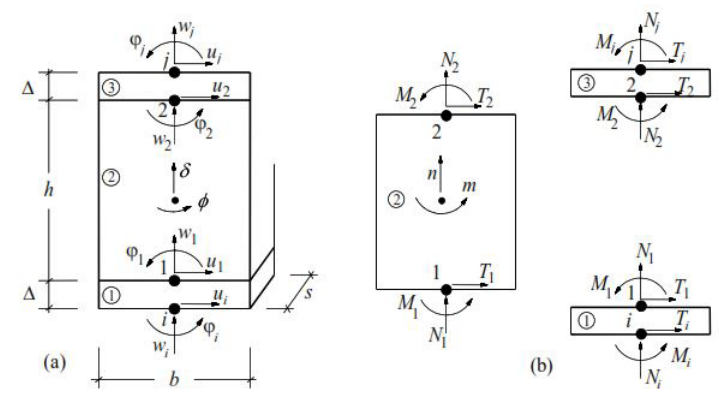

(b)

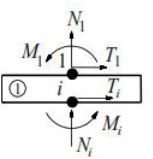

Figure 2: The macro-element kinematic model (Gambarotta and Lagomarsino,1996)

\section{Result and Discussion}

The pushover analysis is performed by means of N2 method, as incorporated in Eurocode 8 (Fajfar P.,1999), (Fajfar P.,2000). By using provision in Eurocode 8, Part 3 damage limit states of the considered buildings was calculated, and seismic capacities was determined. The Pushover Curve along $\mathrm{x}$ and $\mathrm{y}$ direction for considered regular masonry buildings is as given in Figure 3, Figure 4, Figure 5.

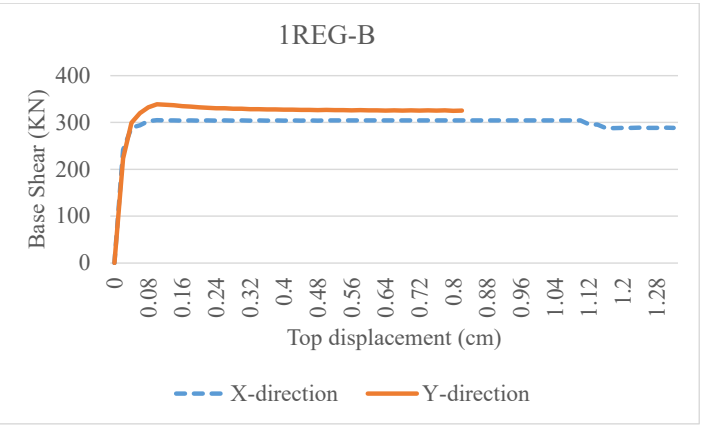

Figure 3: Pushover Curve along $\mathrm{x}$ and $\mathrm{y}$ direction for 1REG Building 
Nepal Engineers' Association, Gandaki

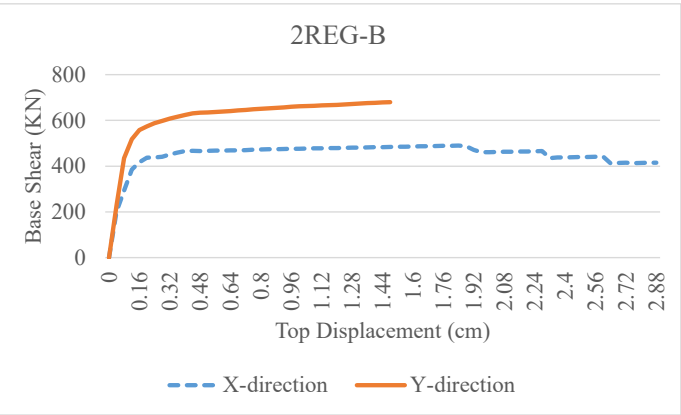

Figure 4: Pushover Curve along $\mathrm{x}$ and $\mathrm{y}$ direction for 2REG Building

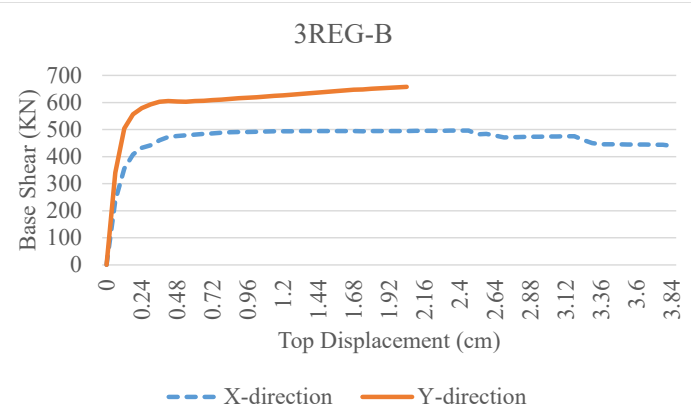

Figure 5: Pushover Curve along $\mathrm{x}$ and $\mathrm{y}$ direction for 1REG Building

The one storey masonry building has lower strength capacity in both directions compared to two and three storey masonry building. The displacement capacity of one storey masonry building is lower than that of two and three storey building. The variation in strength capacity and displacement capacity of two and three storey masonry building is found to be nominal in both $\mathrm{x}$ and $\mathrm{y}$ direction. Comparative data obtained from Pushover Analysis is tabulated in Table 3.
Table 3: Comparative Data Obtained from Pushover Analysis

\begin{tabular}{|l|l|l|l|}
\hline & \multicolumn{3}{|l|}{ Building Model } \\
\cline { 2 - 4 } & 1REG-B & 2REG-B & 3REG-B \\
\hline $\begin{array}{l}\text { Max. Force in x- } \\
\text { direction }(F y *)\end{array}$ & 304.6 & 489.81 & 494.95 \\
\hline $\begin{array}{l}\text { Max. Displacement in } \\
\text { x-direction }(d m *)\end{array}$ & 1.32 & 2.88 & 3.84 \\
\hline $\begin{array}{l}\text { Max. Force in } \\
\text { y-direction }(F y *)\end{array}$ & 338.05 & 679.84 & 657.52 \\
\hline $\begin{array}{l}\text { Max. Displacement in } \\
\text { y-direction }(d m *)\end{array}$ & 0.82 & 1.48 & 2.04 \\
\hline $\begin{array}{l}\text { Displacement/Height } \\
\text { in x-direction }(d m * / H)\end{array}$ & $0.44 \%$ & $0.48 \%$ & $0.43 \%$ \\
\hline $\begin{array}{l}\text { Displacement/Height } \\
\text { in y-direction }(d m * / H)\end{array}$ & $0.27 \%$ & $0.25 \%$ & $0.23 \%$ \\
\hline
\end{tabular}

The failure mechanism of considered buildings from Pushover Analysis as in TREMURI software is presented in Figure 6. From the failure schemes of three buildings, Spandrels are mostly subjected to tension, bending failures and piers are mostly subjected shear failure and damages.

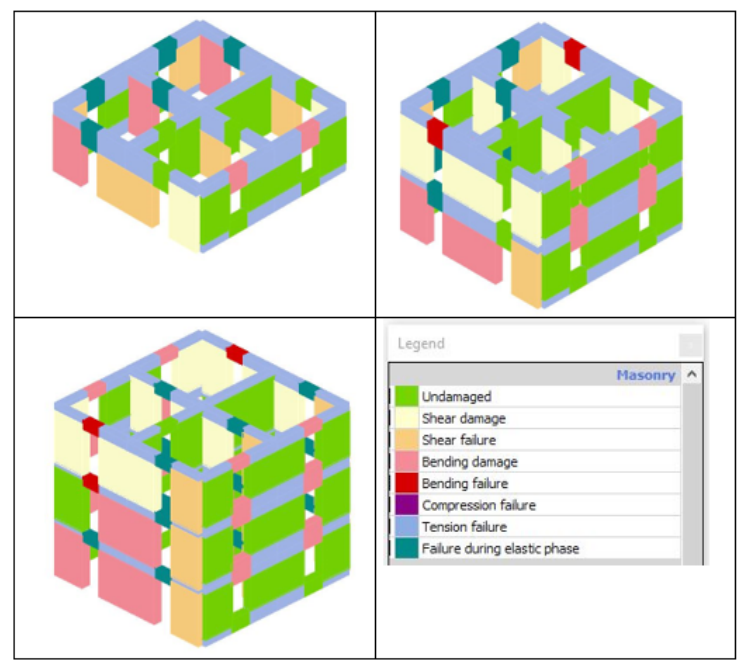

Figure 6: Comparison of the failure mechanism of considered buildings as in TREMURI software 


\section{Conclusion}

Brick masonry building with cement sand mortar is the eldest as well as a common type of building typology in Globe including Nepal. In this research, Static nonlinear analysis of various buildings of the same plans with different numbers of storey are analyzed herein to assess the performance of three different Unreinforced Brick Masonry buildings. The seismic capacity of the building was evaluated by a structural model that uses macro elements for masonry panels. The results of these analysis, expressed in terms of shear and displacements capacities. From the analysis result; capacity curves obtained by static nonlinear analysis shows that the strength and displacement capacities of three storey brick masonry building is more than two and one storey buildings.

\section{References}

Adanur, S. (2010). "Performance of masonry buildings during the 20 and 27 December 2007 Bala (Ankara) Earthquakes in Turkey." Natural Hazard and Earth System Sciences 2547-2556.

CBS- Central Bureau of Statistics. (2012). National Population and Housing Census 2011 Nepal, National Planning Commission Secretariat, Government of Nepal Kathmandu. Eurocode 8(2004) "Design of structures for earthquake resistance." European Committee for Standardization. Brussels, Belgium.

Eurocode 6 (2005) "Design of masonry structures." European Committee for Standardization. Brussels, Belgium.
Fajfar P. (1999): "Capacity spectrum method based on inelastic demand spectra." Earthquake Engineering and Structural Dynamics, Vol. 28 (9), 979-993.

Fajfar P. (2000): "A nonlinear analysis method for performance-based seismic design." Earthquake Spectra, Vol. 16 (3), 573-592.

Gambarotta, L., \& Lagomarsino, S. (1996). “On dynamic response of masonry panels." Proceedings of the national conference on 'Masonry mechanics between theory and practice, Messina, Italy.

Gautam D, Rodrigues H, Bhetwal KK, Neupane P, Sanada Y. (2016). "Common structural and construction deficiencies of Nepalese buildings." Innovative Infrastructure Solutions.

International Code, ed. (2014). "International Building Code 2015 IBC." International Code Council. Country Club Hills, Ill: ISBN: 978-1-60983-468-5.

Kaushik H B, Rai D C \& Jain S K. (2007) "Uniaxial Compressive Stress-Strain Model for Clay Brick Masonry." Current Science, Vol. 92, NO. 4,497-501.

Kaushik, H. B., Rai, D. C., \& Jain, S. K. (2007). "Stress-strain characteristics of clay brick masonry under uniaxial compression." Journal of Materials in Civil Engineering, 19(9), 728-739.

S.T.A. DATA (2018) "User Manual of the software 3Muri S.T.A. DATA, Version 11.5,". S.T.A. DATA srl - C.so Raffaello, 12 - 10126 Torino 